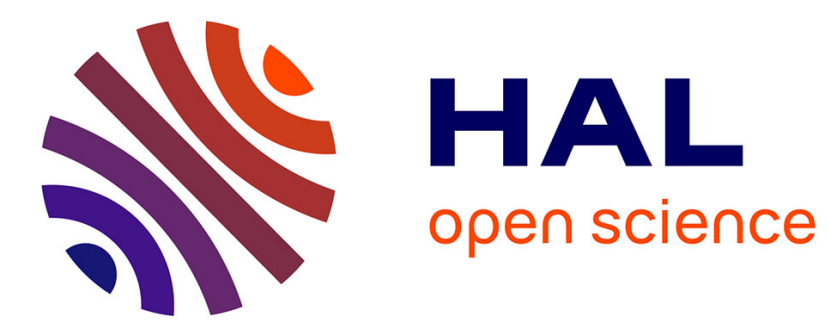

\title{
Revisiting the history of welfare economics
}

Roger E Backhouse, Antoinette Baujard, Tamotsu Nishizawa

\section{To cite this version:}

Roger E Backhouse, Antoinette Baujard, Tamotsu Nishizawa. Revisiting the history of welfare economics. 2020. halshs-02937994

\section{HAL Id: halshs-02937994 https://shs.hal.science/halshs-02937994}

Preprint submitted on 14 Sep 2020

HAL is a multi-disciplinary open access archive for the deposit and dissemination of scientific research documents, whether they are published or not. The documents may come from teaching and research institutions in France or abroad, or from public or private research centers.
L'archive ouverte pluridisciplinaire HAL, est destinée au dépôt et à la diffusion de documents scientifiques de niveau recherche, publiés ou non, émanant des établissements d'enseignement et de recherche français ou étrangers, des laboratoires publics ou privés. 
UMR 5824

93. chemin des Mouilles 69130 Ecully - France

Maison de l'Universite, Bâtiment B 10, rue Trefilerie 42023 Saint-Etienne cedex 02 - France

http://www.gate.cnrs.fr gate@gate.cnrs.fr

\title{
Revisiting the history of welfare economics
}

\author{
Roger E. Backhouse, Antoinette Baujard, Tamotsu Nishizawa
}

\begin{abstract}
:
Our forthcoming book, Welfare Theory, Public Action and Ethical Values challenges the belief that, until modern welfare economics introduced issues such as justice, freedom and equality, economists adopted what Amartya Sen called "welfarism." This is the belief that the welfare of society depends solely on the ordinal utilities of the individuals making up the society. Containing chapters on some of the leading twentieth-century economists, including Walras, Marshall, Pigou, Pareto, Samuelson, Musgrave, Hicks, Arrow, Coase and Sen, as well as lesser-known figures, including Ruskin, Hobson and contributors to the literature on capabilities, the book argues that, whatever their theoretical commitments, when economists have considered practical problems they have adopted a wider range of ethical values, attaching weight to equality, justice and freedom. Part 1 explains the concepts of welfarism and non-welfarism and explores ways in which economists have departed from welfarism when tackling practical problems and public policy. Part 2 explores the reasons for this. When moving away from abstract theories to consider practical problems it is often hard not to take an ethical position and economists have often been willing to do so. We conclude that economics needs to recognise this and to become more of a moral science.
\end{abstract}

\section{Keywords:}

Welfarism, non-welfarism, welfare, public policy, ethics, economics, individualism

JEL codes:

B21, B31, B41, D63, I31






\title{
Revisiting the history of welfare economics ${ }^{1}$
}

\author{
8 June 2020
}

\author{
Roger E. Backhouse ${ }^{2}$, Antoinette Baujard ${ }^{3}$ and Tamotsu Nishizawa ${ }^{4}$
}

\begin{abstract}
Our forthcoming book, Welfare Theory, Public Action and Ethical Values challenges the belief that, until modern welfare economics introduced issues such as justice, freedom and equality, economists adopted what Amartya Sen called "welfarism." This is the belief that the welfare of society depends solely on the ordinal utilities of the individuals making up the society. Containing chapters on some of the leading twentieth-century economists, including Walras, Marshall, Pigou, Pareto, Samuelson, Musgrave, Hicks, Arrow, Coase and Sen, as well as lesser-known figures, including Ruskin, Hobson and contributors to the literature on capabilities, the book argues that, whatever their theoretical commitments, when economists have considered practical problems they have adopted a wider range of ethical values, attaching weight to equality, justice and freedom. Part 1 explains the concepts of welfarism and non-welfarism and explores ways in which economists have departed from welfarism when tackling practical problems and public policy. Part 2 explores the reasons for this. When moving away from abstract theories to consider practical problems it is often hard not to take an ethical position and economists have often been willing to do so. We conclude that economics needs to recognise this and to become more of a moral science.
\end{abstract}

Keywords. Welfarism, non-welfarism, welfare, public policy, ethics, economics, individualism

JEL Codes. B21, B31, B41, D63, I31

\section{Part 1. The problem of welfarism for welfare economics}

Welfare economics is the part of economics that deals with evaluating states of the world and formulating recommendations for policies that would improve the well-being of society as a whole. It covers not only a body of policy advice but, arguably more important, a body of principles on which such evaluations and recommendations should be based. Economists frequently make the claim that how well-off society is, which we refer to as social welfare, depends solely on the well-being of the individuals making up that society. In other words, if a change does not make any individual better off, then social welfare cannot have increased. The claim made in this book is that whether we are talking about old, new or contemporary welfare economics, when economists have tackled practical problems they have adopted a much broader range of ethical judgments beyond welfarism. For example, they have seen greater equality in the distribution as desirable in itself; they have argued that we should respect the rights of individuals to do certain things; and they have attached importance to the way economic outcomes are achieved.

\footnotetext{
${ }^{1}$ This paper includes the preliminary versions of the introduction and of the conclusion of the volume entitled "Welfare Theory, Public Action and Ethical Values: Revisiting the history of welfare economics", edited by Backhouse, Baujard and Nishizawa, that will be published at Cambridge University Press in May 2021.

${ }^{2}$ University of Birmingham and Erasmus University Rotterdam; reb@bhouse.org.uk

${ }^{3}$ Univ Lyon, UJM Saint-Etienne, GATE UMR 5824, F-42023 Saint-Etienne, France ; antoinette.baujard@ univst-etienne.fr

${ }^{4}$ Teikyo University, Faculty of Economics, Tokyo; nisizawa @ier.hit-u.ac.jp
} 
The notion that social welfare depends solely on the well-being, or welfare, of individuals has come to be known as "welfarism." The term "welfarism" appears to have first been used by John Hicks (1959), when he defined it as meaning a concern with "economic welfare," a term used by A. C. Pigou (1920: 11) to denote "that part of welfare that can be brought directly or indirectly into relation with the measuring-rod of money." This excluded considerations such as justice, freedom and rights to which money values could not be assigned. However, the term was not widely used until it was independently invented by Amartya Sen in the late 1970s, who defined it as "The general approach of making no use of any information about the social states other than that of personal welfares generated in them may be called "welfarism"' (Sen 1977, p. 1559). In elaborating on this statement, Sen (1979a, 1979b, p. 464) described welfarism as taking social welfare to depend on nothing other than individual utility information. Welfarism in this sense therefore requires making a distinction between the information needed to establish the welfare of individuals (which might, of course, depend on the welfare of others if people are altruistic), on which social welfare is assumed to depend, from other information, which should be ignored on the ground that it does not affect any one, or at least does not affect them in any relevant way. To give a simple example, if the only thing that mattered to individuals was their own income, then provided the political regime did not affect anyone's income, the welfare economist would not be justified in taking into account whether people lived in a democracy or under a dictatorship. Although this may make the concept seem simple, welfarism is a more complicated concept for there are many ways in which the restriction of information can be specified, and the latter may have many unintended consequences.

Economists, in so far as they have reflected on the history of welfare economics, have typically focused on the transition from the "old" to the "new" welfare economics that took place in the 1930s and 1940s (e.g. Samuelson 1947: 249; Boulding 1952; Little 1950; Graaff 1957, Dobb 1969). ${ }^{5}$ A key element in this transition was the rejection of inter-personal utility comparisons, and therefore of utilitarianism, in favour of a Paretian welfare economics that required as inputs no more than ordinal utilities or preferences. Some questions have been asked about this transition, for example, questioning whether standard accounts leave out economists who were important at the time (Backhouse and Nishizawa 2010). However, none of this historical literature has challenged the assumption that economists adopted a welfarist approach to welfare economics, at least until Sen and other modern welfare economists had developed other conceptions of welfare.

The essays in this book argue that this was not the case and that, even though their statements about welfare theory rarely acknowledged this, economists repeatedly invoked nonwelfarist criteria in their work. Our conclusion is that, despite the focus on welfarism found in most histories of welfare economics, arguments that cannot be accommodated within welfarism have been widespread, the following chapters providing many examples of nonwelfarist thinking by economists who were central to the evolution of welfare economics in the twentieth century.

\footnotetext{
5 There are few histories of modern welfare economics, but these also focus on this transition. The classic example is Blaug 1996, but see also Backhouse 1985, Mongin 2006, Baujard 2017.
} 
If non-welfarist arguments have been pervasive, it is natural to ask whether there is a common underlying reason for why economists have repeatedly violated welfarism, which might be thought of as their "official" methodology. Our answer is that even if economists have focused on welfarist criteria when theorising about welfare, when they become involved in practical problems they more or less have to step outside the welfarist framework (One explanation for this is that many economists hold values that, when examined closely, turn out to be inconsistent with welfarism). For example, Sen (1970a,b) argued that liberalism, a value held by many economists, is inconsistent with Paretianism. However, as we explain below, this is one of several different reasons for moving away from welfarism.

The remainder of this introduction provides a fuller definition of welfarism, which is then used to identify and distinguish the various ways in which economists depart from welfarism. What unites these departures from welfarism is the demands imposed by practice.

\subsection{The meaning of welfarism and non-welfarism}

Sen introduced the term welfarism as follows: "welfarism is essentially an informational constraint for moral judgments about states of affairs." (Sen 1979b: 472). He did this in order to reorientate debates over welfare economics. In his paper, 'On weights and measures: information constraints in social welfare analysis' (Sen 1977), Sen studied the informational properties of individual utility functions and used this way of thinking about utility functions to clarify the problems of intrapersonal and interpersonal comparisons involved in aggregation. The outcome was a major advance in the ability to analyse and criticise the framework of welfare economics, going beyond the former exclusive focus on aggregative issues. Questions of welfare economics were reframed in terms of information: what information is relevant for measuring social welfare and deriving policy recommendations? Is there a problem when we deliberately exclude certain information from our analysis?

This approach is the basis for Sen's key point: "The general approach of making no use of any information about the social states other than that of personal welfares generated in them may be called "welfarism." I would like to argue that (i) welfarism as an approach to social decisions is very restrictive, and (ii) when the information on personal welfare is itself limited, it can be positively obnoxious." (Sen 1977: 1559)

This leads to two distinct definitions of welfarism. The first, possibly less well known, defines welfarism as the claim that social welfare depends only on the welfare of the individuals in the society being considered, but does not need to consider how individual welfare is defined. This implies a bias towards individualism and consequentialism. Other sources of information, for example relating to other moral values or deontological approaches, are not allowable. Sen's second definition of welfarism involves restricting information about what "individual welfare" could mean and how it could be captured. Welfarism is often associated with a focus on subjective, ordinal, individual utilities, such as have become standard in microeconomic theory.

This focus on ordinal utilities and the consequent refusal to make interpersonal utility comparisons very significantly limits the capacity of welfare economics to provide policy recommendations (see Coyle 2019). Welfarism, in this sense, is problematic for many reasons, including that people may adapt to unfair conditions, and because there are operational 
difficulties in gathering reliable information on utility. Coyle (2019, 8), citing Tony Atkinson, argues that, in order to respond to contemporary economic challenges, it is vital to "consider explicitly the moral consequences of particular models". There already exists a substantial literature on axiomatic approaches to problems of social choice and welfare, in which ethical judgments are made explicit, much of which contributes explicitly to non-welfarist approaches. For example, there has been extensive debate over what is commonly known as the informational basis for justice. However, this literature, much of which is technical, involving philosophy as much as economics, has remained substantially separate from much of economic writing, which remains dominated by welfarist thinking.

If we take the first definition of welfarism, the restriction to utility information can be challenged from a normative perspective, turning to values other than utility. Non-welfarism can therefore involve acknowledging issues such as fairness, equity, solidarity and distributional concerns (Kolm 1971, Varian 1974, Fleurbaey and Maniquet 2011). Equality for instance may be the main value at stake (Atkinson 1970), or priority to the worst-off can be expressed by attaching a higher weight to worse-off individuals (Rawls 1971, Parfit 1996). Non-welfarism might also involve taking into account the fact that skills are unequally distributed, that handicaps should be compensated or that responsibility needs to be rewarded (Pazner and Schmeidler 1974, 1978, Roemer 1998a,b, Fleurbaey 2008, Fleurbaey et Bossert 1996). Going beyond welfarism might also involve seeing both utility and freedom as instrinsically important. Such a move might mean defending pluralism in general (Sen 1985b, 2009), or consideration of equity as well as utility (Dworkin 1981a, 1981b; Fleurbaey and Maniquet 2011). Non-welfarism might also involve taking account of information about communities that would be neglected in a welfarist approach. For instance, Taylor's communitarism is clearly non-welfarist (see also Walzer 1983, McIntyre 1988). Some have also claimed that history matters (Nozick 1974), or raised other non-consequentialist concerns (Suzumura and Xu 2001, Xu 2014, Suzumura 2016).

Considering Sen's second definition of welfarism relative to the informational basis for justice, some welfare economists, began to elaborate broader, non-welfarist approaches. ${ }^{6}$ For example, considerations of justice have been used to focus on the provision of primary goods (Rawls 1971), resources (Dworkin 1981a,b), capabilities (Sen 1985a, Nussbaum and Sen 1993), opportunities (Arneson 1990), advantages (Cohen 1989), rights (Gaertner, Pattanaik and Suzumura 1993), freedom of choice (Pattanaik and Xu 1990).

Restricting attention to utility rather than accepting a wider notion of welfare also implies that utility is unidimensional. Non-welfarism allows treating individual welfare as multi-dimensional (d'Aspremont and Gevers 2002). In this sense, synthetic indexes, such as the Human Development Index belong to this family of non-welfarist evaluations.

The allowable information set is closely linked to the possibility of interpersonal comparisons of utility. For instance, if utilities are rationalized using revealed preference theory

\footnotetext{
${ }^{6}$ Note that we use the term non-welfarism (as do Kaplow and Shavell 2001, 2004) but other terms have also been used including "post-welfarism" (Maguain 2002) and "extra-welfarism" (Brouwer, Culyer, Exel and Rutten 2008; Tessier 2009). For reviews of post-welfarist approaches, see Pattanaik (1994); Pattanaik and Xu (2003); Clément, Le Clainche and Serra (2008).
} 
then it does not make sense to make interpersonal, or even intrapersonal, utility comparisons. More generally, the ability to make comparisons, and to derive fairness recommendations depends on one's chosen interpretation of utility. However, in order to overcome Arrow's impossibility theorem, it was often thought necessary to allow for a certain element of interpersonal comparability of utility. That would mean that the restrictions on information associated with welfarism create a risk of making social choice impossible, suggesting that the need to make policy decisions might make it essential to move towards non-welfarism (see Sen 1977b, 1999).

Rehabilitating interpersonal comparisons of utility for such reasons is a major development, for it rests on normative grounds, going against the idea that economics should be an ethically neutral, positive science. On the other hand, the acceptance of interpersonal comparisons of utility does not imply a commitment to non-welfarism. For example, some utililiarians (for example, Harsanyi 1953, 1955, Ng 1999) accept interpersonal comparisons of utility. Conversely, non-welfarism does not imply acceptance for interpersonal comparisons, for some non-welfarist economics reject them (e.g. Fleurbaey, Tungodden and Chang 2003). It is even possible to justify a non-welfarist framework on the basis of ordinal utility only and no interpersonal comparisons, and still go beyond the Arrovian impossibility by introducing strong equity criteria (Mongin and Fleurbaey 2005). ${ }^{7}$

Almost all of these non-welfarist approaches take for granted that value judgements should be taken seriously and transparently explicated. This usually done by capturing an axiomatic approach (see Thomson 2001, Mongin 2003). Normative principles, based on precisely specified value judgments, are expressed in a formal language, before studying the compatibility and their implications. This approach is clearly attractive but, at least so far, it has not led systematically to usable policy recommendations (Fleurbaey 2007).

\subsection{Welfare economics in practice}

When economists try to rule out value judgements, their ability to tackle practical matters is endangered; when they introduce into their welfare theories explicit value judgements that go beyond valuing individual utilities, those theories become non-welfarist. But this book supports the view that there is more than this sharp well-known alternative. As we will argue, when (seemingly welfarist) economists did engage with practice, they frequently step outside the welfarist framework. This is no accident because, in order to offer advice it is necessary to make value judgments and once value judgments are made, there is no reason to

\footnotetext{
${ }^{7}$ There is a continuum of distinct definitions of welfarism. At a technical level, these restrictions of information on utility can be analysed through informational analyses (Sen 1977, d'Aspremont et Gevers 1977, 2002) of utility with invariance conditions. Informational analyses allow to capture, formally and rigorously, a diversity of versions to ordinalism to cardinalism, and comparability to incomparability to comparability of utility. A possible definition of welfarism is a restriction to only strict ordinal preferences. Another one, linked to the Arrovian framework, is a restriction to only binary information on preferences. In the Arrovian framework, you can compare social state $x$ to $y$, and $y$ to $z$, but you have no information whatsoever on the intensity of your preference from $x$ to $y$ as compared to $y$ and $z$. This notably rules out any ordinal information such as information conveyed in the standard marginal rate of substitution. Going from binary to ordinal information is already a departure from a stricter welfarist framework to a less limited set of information, allowing possibilities.
} 
remain within the confines of welfarism. As the essays in this volume show, many economists have introduced non-welfarist elements into theoretical work if only implicitly or unconsciously.

As we have explained, non-welfarism is about being open to information and values that go beyond individual welfare. A helpful way to think about this is through considering the restrictions on information relevant to social welfare implied by different approaches to welfare economics.

1) The old welfare economics of Marshall and Pigou has been said to restrict welfarerelevant information to utility or economic welfare, believed to be measurable in terms of money. In this context, non-welfarism means going beyond a focus on material wealth and aggregates of utilities measured in such terms. In the new welfare economics, welfarism involves a focus on a narrow set of acceptable notions of utility, either for operational reasons, or for the sake of scientific rigor, or by a deep belief that ordinal subjective wellbeing is all that counts for social welfare. In both cases, nonwelfarism, therefore, can involve value pluralism: taking into consideration moral values other than utility, such as freedom, civil rights, equity and distributive concerns.

2) The main feature of welfarism is that, for any concept of welfare, what is important for social welfare is individual welfare. As welfarism involves a focus on individual welfare, however that is defined, any information about groups or societies which is not reducible to information about individuals should be considered irrelevant. But such individualism sometimes fails to capture social welfare. Non-welfarism can therefore mean taking account of information about societies that cannot be reduced to information about individuals.

3) The history of welfare economics has known periods when welfarism has been defended on the basis of consumer's sovereignty on the one hand and scientific rigor on the other. As a corollary, non-welfarism has been often criticized for presenting measurement problems, including the technical difficulties in capturing nonconsequentialist ethics, and for its possible drift into paternalism, notably due to the choice by external experts of relevant objective information. Those welfare economists who have supported a non-welfarist framework have faced these issues and posed solutions when they have engaged with practice.

One way to organise the book would, therefore, be to structure it according to these three different ways in which welfarism has been challenged: taking account of a wider range of information and values, overcoming individualism, tackling the problems posed by nonwelfarism. The issue with such an approach is that, perhaps not surprisingly, most of the economists who challenged welfarism did so in multiple ways. For instance, Peter Cain's reading of Hobson reveals an economist who argued both against restricting attention to economic welfare and against individualism. Kotaro Suzumura's reading of Hicks and of the more recent evolution of normative economics concerns an argument against both monism of values and also the restriction of information on utility. The value of a less unequal distribution, as displayed in Backhouse's argument on Bergson and Samuelson, or in Yamazaki's chapter on Pigou, concern both value monism and individualism. And so on. 
We have, therefore, chosen to arrange the chapters chronologically. It is, however, useful to review the chapters in relation to the different ways in which the economists studied have departed from welfarism when they have engaged with practice.

\subsection{Taking other values into account}

A major feature of economic welfarism is that welfare economics should be restricted to economic welfare - to what Pigou (1920: 11) described as "that part of social welfare that can be brought directly or indirectly into relation with the measuring-rod of money". One interpretation was that this had to be done through the market, and that this implied that material wealth should be all that counts. However, the examples of Ruskin and J. A. Hobson show that, even in Marshall's time, this view was controversial. Alternatively, welfarism can be interpreted as doing no more than impose a single value in that it says that utility is what matters (without any presumption that this depends only on material goods) and anything else matters only in so far as it affects utility. On either interpretation, in such a framework, should other ethical values such as freedom or distributive issues count, they could have no more than instrumental value - valued because they contribute to raising utility. Close examination of major figures commonly taken to be welfarist, including Marshall, Pigou, Samuelson and Coase, shows that this view was never completely accepted.

The history of political economy in Britain during the nineteenth century can be told as an ongoing conflict between economists and their Romantic critics (Winch 1996, 2009). The economists, who include many well-known utilitarians, including the Philosophic Radicals, intellectual descendants of Jeremy Bentham generally focused on the production and consumption of material goods and services, whereas their Romantic critics argued that they neglected higher values and overlooked the human costs of increased production. Among these Romantic critics, the most prominent was the art critic, John Ruskin, who drew on the ideas of the Romantic poet, William Wordsworth, and the social critic, Thomas Carlyle. He may not have been considered an economist himself, but his ideas inspired many who were clearly economists, notably Hobson. Ruskin's economics and his treatment of art have both been studied extensively, but Yuichi Shionoya (Chapter 01) brings the two sides of his thought together. He argues that, in line with the Romantics, Ruskin focused on human nature as a whole, life involving the pleasures and sensations derived from art as much as wealth. There was, therefore, much more to life than mere wealth, for beauty mattered too. Shionoya argues that Ruskin sees life in terms not of the flow of pleasure, but as a stock of capabilities. Ruskin argued that we should focus not merely on self-interest, but on social affection, self-sacrifice and on justice as a criterion for distributing wealth.

It was not just the self-proclaimed heretic, Hobson, who challenged the focus on economic welfare. So too did Alfred Marshall and A. C. Pigou-at different times embodiments of what was seen as economic orthodoxy. Tamotsu Nishizawa (Chapter 02) makes it clear that Marshall worked with a broader concept of wellbeing and a conception of 'organic life-growth', seeing "the vigorous life of the whole" as a more appropriate welfare criterion than utilitarianism. The reason is that he saw economic progress and organic growth as bound up with improvement in human character and capabilities. Yamazaki (Chapter 03) points out that, between the first and second editions of The Economics of Welfare (1924) Pigou extended his definition of welfare to include not only states of consciousness but also "their 
relations". This change made it possible to include equity as an ethical value, entering social welfare independently of the utilities of individuals. Pigou also considered having a variety of individuals was better than having individuals who were all the same. Such judgments, concerning equity and variety are inconsistent with restricting attention to the values and information involved in welfarism. Pigou also parted from simple subjective welfarism when he wrote about the satisfaction of needs — objective, spiritual and urgent — that people might not themselves recognise.

The new welfare economics, the most visible outcome of which was a stress on Pareto efficiency, is commonly perceived as welfarist. The requirement to be scientific was widely taken to mean that the only information available was utility, now understood purely ordinal and subjective. However, one of its main proponents, Paul Samuelson, was willing to depart from welfarism. He used the social welfare function proposed by Abram Bergson (Burk) (1938) to show how ethical values could be used to derive welfare criteria. When confining himself to values that he believed were generally accepted he reached conclusions consistent with welfarism, accepting individuals' judgments of their own welfare. However, as Roger Backhouse (Chapter 04) argues, Samuelson consistently claimed that in order to draw conclusions for policy it was essential to go beyond such judgments. One reason for this was that be believed that policy had to take account of income distribution, an issue on which the Pareto criterion was silent. Another reason was that he attached importance to the process through which outcomes were achieved.

When, in the 1960s, what was taken to be the Pigovian approach was challenged by the Coase Theorem, the argument that negotiation could achieve an efficient outcome, was exclusively about efficiency. This was consistent the new welfare economics and its focus on Pareto efficiency. However, when the Coase Theorem was applied to environmental issues, economists did not remain within this framework but, as Steven Medema (Chapter 05) shows, brought in non-welfarist criteria. The argument that the social optimum involved weighing up the benefit of pollution to the polluter against the harm done to other people was widely challenged using moral arguments that went beyond welfarism, such as the argument that it was immoral to ask victims of pollution to bribe polluters not to pollute. It was argued that societies had value systems that went beyond efficiency and were reflected in social norms and embodied in common law.

Kenneth Arrow, one of the authors of the so-called fundamental theorems of welfare economics, might appear to rely on the normative criterion of Pareto optimality, but Nao Saito (Chapter 06) argues that between the 1950s and the 1990s, Arrow's thinking evolved towards clearly supporting a non-welfarist theories of justice. He attached importance to the public utility of private goods, and to the redistribution of goods or incomes in order to maximize social welfare. He came to consider that majority decision should sometimes be rejected on ethical grounds: decisions favouring discrimination conflicted with his strong belief that discrimination is evil and, because individuals' preferences are blatantly not all that matter, Pareto efficient judgements should be rejected on ethical grounds when they conflict with certain legal rights, as in the case of child trafficking. 


\subsection{Challenging individualism}

If welfare economics is essentially welfarist, with only individual utility counting in assessments of social welfare, collective arrangements or collective values can have no intrinsic significance for welfare economics. This explains why the standard view of welfare economics retains an individualist approach. However, looking back at Hobson, or at the standard authors in welfare economics, such as Marshall, Walras, and Musgrave, and possibly Pigou, Pareto, Samuelson, we find that the individualist bias is less dominant than it is often taken to be.

Hobson, though he positioned himself as a heretic and an outsider-and he was an outsider to Marshall's Cambridge - was taken more seriously by other economists, especially in the United States. His affection for Ruskin presents a puzzle, for Hobson stood in a British liberal, radical tradition that can be traced back to Thomas Paine, whereas Ruskin was a conservative, harking back to an almost medieval way of thinking. Peter Cain (Chapter 07) asks what it was that Hobson found in Ruskin that he did not inherit from the liberal tradition out of which his work emanates. He argues that, from the 1880s, as socialism took hold with Labour representatives entering Parliament, Ruskin's denunciations of the modern, market economy began to look more revolutionary than Hobson's liberalism, leading Hobson to reassess what in Ruskin's work was consistent with the New Liberalism. He could accept Ruskin's ideas about the good life involving more than satisfying given preferences because he saw society as an evolving organism.

Richard Arena (Chapter 08) argues that, despite being the originator of modern general equilibrium theory, Leon Walras believed that society did exist and influenced individuals and that it could not be analysed simply as an aggregate of individuals. If the State can exist independently of individuals, it can make sense to speak of a public interest, for the state has its own ends -its own rationality. These ends include the implementation of justice.

Even the economist whose ideas were central to the creation of a welfare economics centred on individual preferences, Vilfredo Pareto, entertained ideas that departed from pure individualism. Rogerio Arthmar and Michael McLure (Chapter 09) show that, when he turned to sociology, Pareto's views were not welfarist, for he saw people as social beings, acting in response to subjective assessments of the wellbeing of others. Individual utilities evolved in response to the prevailing social equilibrium. In addition, Pareto distinguished between two types of maximum: the maximum for a community, in which the Pareto-criterion is satisfied, and the maximum of a community in which the maximization is not constrained by the requirement that no one is made worse off, and in which the utilities of different individuals are weighted.

Another important example of an economist who created a space for the social was Richard Musgrave, author of what was at one time the standard text on public finance. As Maxime Desmarais-Tremblay (Chapter 10) explains, Musgrave saw great technical and political merits in individualism but he consistently argued implicitly for a more collective approach to the provision of "merit" goods. Early on, he argued that a socially important needs could be identified through taking account of the "cultural, political and social forces" operating in a society, while later, he made arguments for redistribution that made sense only in relation to a community, defending notions such as the equal-sacrifice criterion for taxation. 
In the 1980s, working together with Peggy Musgrave, he argued even more strongly for the existence of community interests, criticizing theories based on self-interest as too narrow.

\subsection{Questioning non-welfarism}

Economists have often assumed that, if it is to achieve its scientific objectives, welfare economics should either be free of any value judgments, attributing such a view to Lionel Robbins (1932), or it should be based only on generally accepted value judgments. Considering only utility information so that the only judgments involved are those that come from individuals whose welfare is being analysed was, therefore, a way to defend the consumer's sovereignty, generally considered more acceptable in a free society than, paternalism. However, even the economists most closely associated with the welfarist approach, when considering operational issues and practical matters, came to support a non-welfarist framework. Conversely, when some welfare economists who support a non-welfarist framework have engaged with practice, they have faced issues of measurement and paternalism, being forced to provide solutions.

Kotaro Suzumura (Chapter 11) examines the work of John Hicks whose "Manifesto" $(1959,1981)$ used the term "Economic Welfarism" as a label for the view that he did not hold. He asks how far Hicks was prepared to go from welfarism, concluding that he was prepared to abandon consequentialism: not only a wide set of consequentialist information may be relevant besides utility, some non-consequentialist information could also be invoked along, such as opportunity sets, procedure, and rights. It is significant that this departure from welfarism came in a book titled Essays in World Economics, for this makes clear that the context was dealing with practical problems. Suzumura responds to Hicks's challenge to welfarism by drawing on the past fifty years of normative economics to explore the possibilities for integrating nonwelfarist and non-consequentialist information into the analysis of welfare.

Because it was Sen who stimulated modern discussions of welfarism and nonwelfarism, the case that he challenged welfarism does not need to be made. One well-known aspect of Sen's contribution to justice issues is the capability approach, presented as an alternative to both "utility fetishism" and "resource fetishism" (Sen 1985a, 1985b). However, describing Sen's capability approach as the alternative to standard welfare economics would fail to capture the major turning point represented by the capability approach, and would involve a misunderstanding of Sen's much more drastic criticism of welfarism.

Constanze Binder (Chapter 12) presents the wide diversity of capability approaches after Sen and Martha Nussbaum introduced the notion. All capability approaches seek to justify normative theories of justice and to provide operational tools for the evaluation of decisionmaking which overcome the issues raised by welfarism. Some attach intrinsic importance to freedom, some tackle the issues of preference adaptation, and some avoid the neglect of diversity which is can arise in the context of paternalism. However, Binder argues that none of them succeed in providing a satisfactory response to all three challenges. In other words, some problems occurring with welfarism may reappear with non-welfarism. Binder explains why this is so, and argues that a way out of this problem requires more attention to democratic values, such as human agency.

Given that Sen is generally considered one of the pre-eminent contemporary welfare theorist and social choice theorist, it is not obvious that his movement beyond welfarism came 
in the context of addressing practical problems. That this was the case is argued by Muriel Gilardone (Chapter 13), who links Sen's development of the capability approach to his extensive work on theories of justice and to his applied work on poverty, inequality and entitlements. His theoretical welfare economics is part of a novel approach in which, with a particular consideration of avoiding paternalism, agency and public reasoning are the core elements.

\subsection{Concluding remarks}

The technical limitations of welfarism come with consequences on a restriction of possible value judgements. The individualist framework itself, focusing on individual welfare only, excludes relevant values and obscure certain relevant information and solutions at the collective level. The restriction of information on utility impedes to express certain desirable ethical views. We have shown that welfare economists did not respect these limitations when they face the problems this causes in practical context. Our concluding on Sen's scrutiny is a way to open the discussion and show that the consideration of information has democratic stakes.

The essays in this volume show that, at least since the nineteenth century, when economists have faced practical problems such as public decision-making, concrete environmental or social concerns, they have abandoned one or more of the features of welfarism, adopting a non-welfarist approach. They have taken account of dimensions of welfare that cannot be measured, such as distributive justice and freedom of choice, paying attention to more than the satisfaction of preferences, and more information on utility that what the framework of welfare economics imposed. They have viewed welfare from a social point of view and they have introduced value judgments going beyond the very narrow range of values generally considered uncontroversial. The essays included here are clearly not comprehensive in their coverage; that would be impossible. But they cover many of the major figures in twentieth century welfare economics-Marshall, Pigou, Pareto, Hicks, Samuelson, Coase, Musgrave, Arrow and Sen. Even though we also consider some self-consciously heterodox economists, notably Ruskin and Hobson, the instances of non-welfarist thinking that are presented here should not be dismissed as the views of minor, marginal figures for they were very influential in their own day. In view of this, there is a strong case that the history of welfare economics needs to be rewritten, and we regard this book as a first step in that process.

\section{Bibliography of Part 1.}

Adler, M. D. 2012. Well-being and fair distribution. Beyond cost-benefit analysis. Oxford University Press, New York (NY).

Arneson, R. J. 1990. Liberalism, distributive subjectivism, and equal opportunity for welfare. Philosophy \& Public Affairs 19, 158-194.

Arrow, K. J. 1951. Social Choice and Individual Values. New York: Wiley. (Second edition, New Haven and London: Yale University Press, 1963).

Arrow, K. J, and Debreu, G. 1954. Existence of an Equilibrium for a Competitive Economy. Econometrica, 22(3), 265-290.

Arrow, K. J. and T. Scitovsky (eds) Readings in Welfare Economics. London: George Allen and Unwin, 1969.

Atkinson, A. B. 1970. On the measurement of inequality. Journal of Economic Theory 2(3), 244-63. 
Backhouse, R. E. 1985. A History of Modern Economic Analysis. Oxford: Basil Blackwell.

Backhouse, R. E., and Nishizawa, T. 2010. No Wealth but Life: Welfare Economics and the Welfare State in Britain, 1880-1945. Cambridge: Cambridge University Press.

Bator, F.M. 1958. The Anatomy of Market Failure. The Quarterly Journal of Economics, 72(3), 351-379.

Baujard, A. 2014. A utility reading for the history of welfare economics. Mimeo Gate Lyon Saint-Etienne.

Baujard, A. 2016. "Utilitarianism and anti-utilitarianism", in Gilbert Faccarello and Heinz D. Kurz (Eds.), Handbook of the History of Economic Analysis, Vol. 3, Ch.39 : 577-588, Edward Elgar Publishing Limited, Cheltenham (U.K.).

Baujard 2017. L'économie du bien-être est morte. Vive l'économie du bien-être !", in G. Campagnolo et J.S. Gharbi (Eds.), Philosophie économique, Ch.2 : 77-128, Editions Matériologiques, 2017.

Baujard, A. and M. Gilardone 2017. Sen is not a capability theorist, Journal of Economic Methodology 24(1), 119.

Baujard, A. M. Gilardone and M. Salles. “A conversation with Amartya Sen”, To be published in Social Choice and Welfare. (Video overview available on http://www.unicaen.fr/recherche/mrsh/forge/262)

Baumol, W. J. 1946. Community indifference. Review of Economic Studies 14(1), 44-48.

Bergson (Burk), A. 1938. A Reformulation of Certain Aspects of Welfare Economics. The Quarterly Journal of Economics, 52(2), 310-334.

Blaug, M. 1996. Economic Theory in Retrospect, $5^{\text {th }}$ edition. Cambridge: Cambridge University Press.

Brouwer, W. B. F., Culyer, A. J., van Exel, N. J. A., and Rutten, F. F. H. 2008. Welfarism vs. extra-welfarism. Journal of Health Economics 27(2), 325-38.

Chipman, J. S., and Moore, J. C. 1978. The new welfare economics, 1939-1974. International Economic Review 19: 547-84.

Coase, R. H. 1960. The problem of social cost. Journal of Law \& Economics, 3 (Oct), 1-44.

Clément, V, C. Le Clainche and D. Serra, 2008. Economie de la justice et de l'équité. Economica.

Cohen, G. A. 1989. On the currency of egalitarian justice. Ethics 99(4), 906-944.

Coyle, D. 2019 Homo Economicus, AIs, humans and rats: decision-making and economic welfare. Journal of Economic Methodology, 26(1), 2-12.

d'Aspremont, C., and Gevers, L. 1977. Equity and the informational basis of collective choice. Review of Economic Studies 44(2), 199 -209.

d'Aspremont, C., and Gevers, L. 2002. Social welfare functionals and interpersonal comparability. In: Arrow K.J., Sen A.K., Suzumura K. (eds) Handbook of social choice and welfare, vol 1. Amsterdam: Elsevier.

Dobb, M. 1969. Welfare economics and the economics of socialism, Cambridge University Press.

Dworkin, R. 1981a. What is equality? part 1: Equality of welfare. Philosophy \& Public Affairs 10(3), 185-246.

Dworkin, R. 1981b. What is equality? part 2: Equality of resources. Philosophy \& Public Affairs 1(4), $283-345$.

Fleurbaey, M. 2007.

Fleurbaey, M. 2008. Fairness, Responsibility, and Welfare, Oxford University Press.

Fleurbaey, M., Tungodden, B., and Chang, H. F. 2003. Any non-welfarist method of policy assessment violates the Pareto principle: a comment. Journal of Political Economy 111(6), 1382 -1385.

Fleurbaey, M., and Maniquet, F. 2011. A Theory of Fairness and Social Welfare. Cambridge: Cambridge University Press.

Gaertner, W, P. Pattanaik and K. Suzumura 1992. Individual rights revisited, Economica 59S, 161-177.

Galbraith, J. K. 1958. The Affluent Society. London: Penguin Books.

Graaff, J. de V. 1957. Theoretical Welfare Economics. Cambridge: Cambridge University Press.

Harsanyi, J. 1953. Cardinal utility in welfare economics and in the theory of risk-taking. Journal of Political Economy 61(5), 434-435.

Harsanyi, J. C. 1955. "Cardinal Welfare, Individualistic Ethics, and Interpersonal Comparisons of Utility." Journal of Political Economy 63 (4), 309-21.

Hicks, J. R. 1939. The foundations of welfare economics. Economic Journal 49(196), 696-712.

Hicks, J. R. 1941. The rehabilitation of consumers' surplus. Review of Economic Studies 9, 108 -16.

Hicks, J. R. (no date; c. 1955): “Another Shot at Welfare Economics, Lecture I and Lecture II," unpublished typescript, 19 pages folio +21 pages, diagrams in the text. 
Hicks, 1959. A preface and a manifesto, in Essays in World Economics. Oxford: Clarendon Press, viii-xiv. Reprinted in Arrow and Scitovsky, 1969.

Igersheim, H. 2017. The Death of Welfare Economics: History of a Controversy. CHOPE Working Paper, 201703, 1-37.

Kaldor, N. 1939. Welfare Propositions of Economics and Interpersonal Comparisons of Utility. The Economic Journal, 49(195), 549-552.

Kaplow, L., and Shavell, S. 2001. Any non-welfarist method of policy assessment violates the Pareto principle. Journal of Political Economy 109(2), 281-6.

Kaplow, L., and Shavell, S. 2004. Any non-welfarist method of policy assessment violates the Pareto principle: reply. Journal of Political Economy 112(1), 249-51.

Kolm, S.-C. 1971. Justice et équité, Paris, CEPREMAP; new edition, Paris, CNRS 1972 ; English version 2002, Justice and equity, MIT Press.

Little, I.M.D. 1949. Economic Behaviour and Welfare. Mind, 58(230), 195 -209.

Little, I.M.D. 1951. A Critique of Welfare Economics. Oxford: Oxford University Press.

Lipsey, R.G., and Lancaster, K. 1956. The General Theory of Second Best. Review of Economic Studies, 24(1), 11.

McIntyre, A. 1988. Whose Justice? Which Rationality? University of Notre Dame Press.

Maguain, D. 2002. Les théories de la justice distributive post-rawlsiennes. Une revue de la littérature. Revue Economique 53(2), 165-199.

Marshall, A. 1890-1920. Principles of Economics. London: Macmillan.

Mill, J. S. 1848. Principles of Political Economy and Some of their Applications to Social Philosophy.

Mongin, P. 2003. L'axiomatisation et les théories économiques. Revue Economique, 54(1), 99-138.

Mongin, P. 2006. Is there progress in normative economics? Economics and Philosophy 22, 19-54.

Mongin, P., and Fleurbaey, M. 2005. The news of the death of welfare economics is greatly exaggerated. Social Choice and Welfare 25(2), 381-418.

Musgrave, R. 1959. The Theory of Public Finance: A Study in Public Economy. New York: McGraw Hill.

Nozick, R. 1974. Anarchy, State and Utopia, New York: Basic books, Inc., Publishers.

Ng, Y.-K. 1999. Utility, informed preferences, or happiness : Following Harsanyi's argument to its logical conclusion. Social Choice and Welfare 16(2), 197-21.

Nussbaum, M. C. et Sen, A. K. 1993. The Quality of Life. Clarendon Press, Oxford, Edition 2001.

Pattanaik, P.K. 1994, Some non-welfaristic issues in welfare economics. In B. Dutta (Ed.), Welfare Economics, Oxford University Press, pp. 197-248.

Pattanaik, P.K. et Xu, Y. 1990. On ranking opportunity sets in terms of freedom of choice. Recherches Economiques de Louvain 56(3/4) : 383-390.

Pattanaik, P.K. et Xu, Y. 2003. Non-welfaristic policy assessment and the Pareto principle. Public Choice Conference, Nashville.

Pazner, E. A., and Schmeidler, D. 1974. A difficulty in the concept of fairness. Review of Economic Studies 41(3), 441-3.

Pazner, E. A. and Schmeidler, D. 1978. Egalitarian equivalent allocations: a new concept of economic equity. Quarterly Journal of Economics 92(4), 671-87.

Pigou, A. C. 1912 Wealth and Welfare. London: Macmillan.

Pigou, A. C. 1920-1932 The Economics of Welfare. London: Macmillan.

Rawls, 1971. A Theory of Justice. Cambridge, MA: Harvard University Press.

Robbins, L. C. 1932. Essay on the Nature and Significance of Economic Science. London: Macmillan. Second edition 1935.

Roemer, J. 1998. Equality of Opportunity, Cambridge University Press.

Samuelson, P. A. 1947. Foundations of Economic Analysis. Cambridge, MA: Harvard University Press.

Samuelson, P. A. 1950. Evaluation of Real National Income. Oxford Economic Papers, 2(1), 1-29.

Scitovsky, T. 1941. A note on welfare propositions in economics. Review of Economic Studies 9: 77-88. Reprinted in Arrow and Scitovsky 1969.

Sen 1970a. Collective Choice and Social Welfare. San Francisco: Holden Day. 
Sen, A.K. 1970b. The Impossibility of a Paretian Liberal. Journal of Political Economy, 78(1), 152-157.

Sen, A.K. 1977. On Weights and Measures: Informational Constraints in Social Welfare Analysis. Econometrica, 45(7), 1539-1572.

Sen, A.K. 1977b. Social Choice Theory: A Re-Examination, Econometrica, 45(1), 53-89

Sen, A.K. 1979b. Utilitarianism and Welfarism. The Journal of Philosophy, 76(9), 463-89.

Sen, A.K. 1979a. Personal Utilities and Public Judgements: Or What's Wrong With Welfare Economics. The Economic Journal, 89(355), 537-558.

Sen, A.K. 1979c. Equality of what ? In The Tanner Lectures on human Values, S. McMurrin, Ed., vol. 1. Cambridge University Press, Cambridge, 1979. New edition in A. K. Sen, Choice, Welfare and Measurement, MIT Press, Cambridge, pp. 365-366, 1982.

Sen, A.K. 1985a. Commodities and Capabilities. Oxford University Press.

Sen, A. K. 1985b. Well-being, agency and freedom : The Dewey Lectures 1984. The Journal of Philosophy 72(4), 169-221.

Sen, A.K. 1999. The Possibility of Social Choice. American Economic Review, 89 (3), 349-378.

Sen, A.K. 2009, The idea of justice, Cambridge, MA: The Belknap Press of Harvard University Press.

Stigler, G. J. 1966. The Theory of Price, $3^{\text {rd }}$ edition. New York: Macmillan.

Suppes, P. 2005. The pre-history of Kenneth Arrow's social choice and individual values. Social Choice and Welfare, 25(2/3), 319-326.

Suzumura, K. 2016. Choice, preferences, and procedures : a rational choice theoretic approach, Cambridge : Harvard University Press.

Tessier, P. 2009. Harsanyi, Sen ou Bentham. Quelle perspective adopter pour l'évaluation du bien-être en santé ? Revue Economique 60(6), 1309-1333.

Thomson, W. 2001. On the axiomatic method and its recent applications to game theory and resource allocation. Social Choice and Welfare 18: 327-386.

Varian, H. R. 1974. Equity, envy, and efficiency, Journal of Economic Theory 9: 63-91.

Walzer, M. 1983. Spheres of justice. Basic Books.

Winch, D. M. 1996. Riches and Poverty: An Intellectual History of Political Economy in Britain, 1750-1834. Cambridge: Cambridge University Press.

Winch, D. 2009. Wealth and life: essays on the intellectual history of political economy in Britain, 1848-1914. Cambridge University Press. 


\subsection{Theory and practice}

In the introduction ${ }^{9}$ to the volume we focused on various definitions of welfarism in order to create a list of ways in which economists might depart from it. Whichever definition we adopt, welfarism implies that the only information relevant to social welfare is the utilities of individuals: that if no-one's utility is affected by some change then social welfare cannot be affected. Conversely, non-welfarism occurs when economists start to depart from such informational restrictions. For example, it is possible to remain an individualist, but to take account of information that goes beyond individuals' utilities. It is also possible to question individualism, taking the position that social welfare may have a social dimension, not reducible to the utilities of individuals making up the society. Once the move from welfarism has been made, numerous ethical issues arise, from whether to embrace non-consequentialist ethics to the dangers of paternalism when welfarism is abandoned.

Economists often talk of "the fundamental theorems of welfare economics:" that, subject to certain conditions, every competitive equilibrium is Pareto-efficient, and that every Pareto-efficient allocation can be achieved as a competitive equilibrium provided that endowments can be suitably allocated. ${ }^{10}$ Such language places Pareto-efficiency at the heart of welfare economics, which makes sense if, and only if, a welfarist approach is adopted. Thus, in as far as economists emphasize the concept of Pareto-efficiency, it is natural to conclude that their approach is welfarist. In contrast, as the Introduction tried to make clear, the chapters in this volume show that economists, including some of those most closely associated with the emergence of the mainstream of economics, have repeatedly engaged in non-welfarist analysis.

We also made the claim that these departures from welfarism occurred when economists engaged with practice but in the Introduction we did not explain why this was the case. Why should consideration of practice make it more difficult to sustain a welfarist position than when engaging with pure theory? ${ }^{11}$ It is easy to explain the appeal of welfarism when economists remain at the level of theory. Individualism has obvious attractions and when combined with the analytical tractability of the concept of Pareto-efficiency, or utilitarianism, there is a strong incentive to adopt a welfarist perspective. In contrast, when economists turn to practice, they face problems that push them away from welfarism.

\footnotetext{
${ }^{8}$ Part 2 displays the conclusion of the volume "Welfare Theory, Public Action and Ethical Values: Revisiting the history of welfare economics", edited by Backhouse, Baujard and Nishizawa, that will be published at Cambridge University Press, May 2021.

${ }^{9}$ See Part 1 of this working paper.

${ }^{10}$ Blaug (2007) discusses the history of the fundamental theorems. In that he argued that some of the "classic" authors cited, notably Adam Smith, were not thinking in terms of the static equilibrium framework that underlies the fundamental theorems, his conclusions are consistent with ours.

${ }^{11}$ In the interests of simplicity and clarity, we write as though there is a clear distinction between theory and practice, but nothing depends on this. We accept that such a distinction is impossible to draw precisely, being analogous to the problem of defining "applied" economics (see Backhouse and Biddle 2000; Backhouse and Cherrier 2017). For example, whether a game-theoretic analysis of particular type of auction is theory or application is unanswerable outside a specific context. What can be said is that the closer an economist is to practice, the stronger the factors we discuss here become.
} 


\subsection{Reasons for moving beyond welfarism}

A strict welfarist approach leads naturally to an emphasis on the Pareto criterion: that the only case in which one can be sure that a change is welfare-enhancing is when it makes at least one person better off without making anyone worse off. To go beyond that requires making interpersonal utility comparisons, or the introduction of some additional criterion that goes beyond welfarism. This may be unproblematic for the theorist, who can conclude that equilibria are, or are not, Pareto-efficient. However, in practice, outside the world of abstract, simplified models, the Pareto criterion typically provides insufficient guidance. This may not necessitate going beyond welfarism - for example, it might be possible to adopt a utilitarian approach — but in practice it usually does, for several reasons.

\section{i) Awareness that other values matter}

Economists have argued that, at least in Western, democratic societies, individualism and the Pareto criterion are generally accepted values. Other values are more controversial. However, when deriving normative conclusions about policy and social decisions, economists have frequently introduced other values including:

- a fair distribution of resources (Pigou discussed in chapter 4, Samuelson in chapter 8, Musgrave in chapter 10, Arrow in chapter 11);

- freedom, autonomy and liberal values (Hobson discussed in chapter 02, Hicks in chapter 7, Capabilitarianism in chapter 12, Sen in chapter 13);

- fulfillment and quality of life (Hobson discussed in chapter 2, Marshall in chapter 3, Capabilitarianism in chapter 12, Sen in chapter 13);

- the formation of human character (Ruskin discussed in chapter 1, Hobson in chapter 2, Marshall in chapter 3);

- the intrinsic importance of the environment (Ruskin discussed in chapter 1, and many environmental economists described in chapter 9);

- the provision to everyone of primary goods or needs (Pigou discussed in chapter 4, Rawls in chapter 7);

- equality of opportunity and non-discrimination (Hobson discussed in chapter 2, Arrow in chapter 11).

It is clear why such issues have been unattractive to theorists preferring to remain neutral over values. These issues are controversial, often hard to define precisely, and they raise questions about how different values are to be weighed against each other. One reason why it is difficult to weigh these aims against each other is that some of them are linked to means rather than ends. Provision of primary goods is arguably a means, whereas utility and quality of life are ends. Other aims, such as equal opportunity, rights and liberal values will be means for some people and ends for others. The multi-dimensionality of some of these ends also poses problems, as does the requirement, common in a policy context, that decisions should be based on objective information. Problems also arise because of inter-dependencies in society and the different ways in which this can be conceptualized. For example, where Hobson and Marshall saw society as an organism, Pigou, Musgrave and environmental economists focus more narrowly on inter-dependence that can be captured through concepts of public goods and externalities. 
However, even if these aims pose great theoretical and conceptual problems, they are often inescapable when offering advice on practical problems, in specific political and social contexts. For example, as Medema showed in Chapter 9, environmental economists have debating the implications of the Coase Theorem in the 1970s could not avoid confronting the question of whether it was fair to force victims of pollution to bribe polluters to reduce emissions. In late-Victorian England, on the other hand, the evolution of human character was an issue that would often be raised when policies were discussed and it was common for economists to take a paternalist attitude towards the working classes in a way that would be unacceptable today. Ruskin (discussed in chapter 1 and 2) imposed values closely related to his views on art and was clearly paternalist. Marshall's position was different, but, as Nishizawa's discussion in Chapter 3 shows, when discussing policy, he attached great importance to the elimination of poverty and securing the material means necessary for all people, including the working classes, to have a full life and to develop their human faculties. This dependence on the specific political and social context accounts for the great diversity in cases studies in the different chapters. However, beneath this diversity there remain important common features.

\section{ii) Difficulties with getting reliable or meaningful information}

Pigou (discussed by Yamazaki in chapter 4) assumed that measurement was possible for what he called economic welfare - that part of welfare that could be measured in terms of money. This implies a neat separation between the realms of economics (economic welfare) and ethics (non-economic welfare). However, as Suzumura (chapter 7) explains, there are serious operational problems that make it difficult to draw a clear distinction between what belongs to economics and what belongs to ethics - between facts and values. Pigou's monetary test, the idea for which he took from Marshall, sounds attractive but is in practice difficult to apply, raising serious problems for welfare economics. Suzumura (chapter 7) recalls Putnam's opinion (2002, p. 44): "The worst thing about the fact/value dichotomy is that in practice it functions as a discussion-stopper, and not just a discussion-stopper, but a thought-stopper." A similar claim was made by Samuelson (chapter 8) when he argued that utility and welfare were two distinct concepts, each requiring different types of information. For example, the difficulties involved in comparing different individuals' utilities make it difficult to even to conclude that trade is better than no trade whenever trade makes one person better off and another worse off.

\section{iii) Observed problems with market outcomes}

The theorist typically works with abstract goods, implying that there is no basis for privileging some goods over others. In contrast, when engaging with specific practical problems, in which goods are identified, it may become clear that certain goods are more important than others. For example, it may become clear that certain goods need to be provided in a society in which there are social interactions and unavoidable externalities - that they should be considered as "merit goods" (Musgrave, chapter 10). It may be that people do not realise how valuable these good are, or that the benefit to society exceeds the benefits individuals derived from purchasing them. Similar issues arise with the provision of public goods, which will typically be under-provided by the market. It is easy for the theorist to ignore such goods but when tackling specific applied problems, it will be harder to avoid them. 
Much the same can also be said of income distribution. When operating at an abstract level, the economist may ignore problems of inequality and poverty in order to focus on other things. As Pigou (chapter 4) recognized, people have different tastes and this will have consequences for their choices and actions, making it difficult to assess how far inequalities are the result of individual choice and how far they indicate unfair treatment of some people that needs to be put right. However, it may become harder to ignore inequality or poverty when confronted with specific instances of poverty and the consequences of an unequal distribution of income. For example, child poverty often provokes a reaction of indignation. Tackling child poverty is impossible without addressing the situation of the families in which children are located, implying a need to address distributional issues that go beyond welfarism Among economists discussed here, Samuelson (see chapter 8) argued repeatedly that the value judgments involved in Pareto-efficiency would need to be supplemented by other ethical criteria.

\section{iv) Individuals and society}

Objections to using individual preferences or utilities as a measure of welfare is reinforced if individuals are seen as social creatures, whose preferences are influenced by the societies in which they live. In the modern world, it is hard not to take such a view. Besides, as individual are embedded in a network of multiple interrelations, their welfare is strongly affected by a number of external, agglomeration, or spillover effects. This explains a strong departure from, not only ethical individualism but also methodological individualism. As Walras (quoted in chapter 5, p. 15) argued, "When human beings (...) act in order to consume, produce and survive, they cannot ignore the existence of the division of labor and therefore the interdependence and the solidarity among all human destinies." As Desmarais-Tremblay explains in chapter 10, Richard Musgrave held strongly to such a view. There is a long tradition, running at least from Thorstein Veblen to John Kenneth Galbraith, that illustrates the way in which wants are socially determined. People are inter-dependent.

\section{v) Issues relating to paternalism}

In the nineteenth century, it was common for economists, generally members of the upper classes, to adopt a paternalist attitude towards the working classes. Marshall's views about how the working classes could improve themselves, discussed in chapter 3, have already been noted. In a similar manner, Hobson (discussed in chapter 2) assumed that his ethical values about the relative merits of different activities and types of consumption were generally held. Such views are not surprising in a world in which it was routine to view Western society, run by white, upper class men, as the apex of civilization. In contrast, for modern economists, paternalist attitudes need to be justified (something Musgrave, discussed in chapter 10, tried to do).

The situation was very different in the liberal western societies fighting communism in the post-war period. In those societies, individuals were considered are the best judge of their own interests (see Amadae 2002). This made welfarism very attractive on account of its respect for individuals' subjective preferences and its avoidance of paternalism. Changes in society can therefore go a long way towards explaining the shift from paternalism in the early twentieth century towards non-paternalist views and the emergence of welfarism based on subjective utilities from the 1930s onwards. 
In contrast, when tackling specific applied problems, it is harder for economists, whatever their philosophical or ideological preferences, to avoid some of the objections to welfarism and eventually justify a need for paternalism. As Samuelson (quoted in chapter 8, p. 23) asks, "what about the person choosing suicide even though, if he remained alive, he would soon change his mind?" Similar issues in the context of addiction (an addict may wish he or she may regret having developed an addition) and more generally with activities the consequences of which are unknown at the time choices are made. In other words, subjective preferences, as they exist when individuals take decisions, may not be the appropriate criterion by which to assess the consequences of an action for someone's welfare. Whilst the economic theorist can ignore these issues, using hostility to paternalism as a defense of this strategy, such a defense becomes more difficult when operating at a more concrete, practical level, and this makes it easier to support non-welfarist arguments.

It is however often difficult to justify non-welfarist views without falling into paternalism. For example, within capabilitarian theories, if an economist identifies the list of basic functionings for a person, he is being paternalist towards her as she could not have a voice on what she personally has reasons to value (chapter 12). Because he values human agency, Sen has supported public deliberation in order to provide legitimacy for the information used in welfare economics (chapter 13). Conclusions derived from welfare theories, whichever welfarist or non-welfarist, may be conducive to a richer public debate, but they cannot be a substitute for it.

\subsection{Economics as a moral science}

As we have explained, welfarism is attractive to many economists. It clearly respects individualism and avoids problems of paternalism. It also fits well with the aim, clearly articulated by Lionel Robbins (1932), to make economics into a science, with positive economics clearly demarcated from ethics. As Robbins contended, people differ fundamentally in their ethical views and it is not the task of the economic scientist to arbitrate between different ethical positions. However, as this volume shows, when economists have turned to practical problems they have frequently turned to non-welfarist arguments for reasons discussed in the previous section. In doing this, many economists have, whether consciously or unconsciously, brought additional ethical judgments, beyond individualism and nonpaternalism, to bear on economic problems.

One result of Robbins's injunction was that, from around the 1960s, welfare economics effectively disappeared from much of economics (Atkinson 2001). The background to that was that there was, for many years, great doubt about what welfare economics could achieve. Hicks (1939: 697) wrote of "the euthanasia of our science." He believed that compensation tests provided grounds for reversing this, but this optimism did not last long. The work of Tibor Scitovsky, Kenneth Arrow, Ian Little Paul Samuelson and Jan de V. Graaff, seemed to imply that welfare economics was impossible (Mishan 1960: 218; see also Chipman and Moore 1978, Mongin 2006, Igersheim 2019). However, what Atkinson meant by "the strange disappearance of welfare economics" was not that economists stopped making normative statements, but that, from around the 1960s, they stopped analyzing the principles underlying normative statements, 
something that had it had been common for earlier generations of economists to do. ${ }^{12}$ Where economists did discuss welfare issues from a theoretical point of view, the dominant approach centred on Pareto efficiency and what came to be called the two fundamental theorems of welfare economics, rigorously proved by Kenneth Arrow and Gerard Debreu (1954). This terminology, of "fundamental theorems," appears to date from much the same time as the time to which Atkinson dates the disappearance of welfare economics (Blaug 2007).

However, what happened was not consideration of the principles underlying welfare economics disappeared, but that this became a specialized activity. Taking its cue from the work of Arrow, John Harsanyi, John Rawls and others, a new field of welfare economics emerged, placing the subject on an axiomatic foundation. This field, symbolized by the journal Social Choice and Welfare, developed as an interdisciplinary field straddling the boundaries between economics, philosophy and political science (see in this regard Fleurbaey 2000, 2007, Mongin and Fleurbaey 2005). This, of course, is the background to the work discussed in chapters 7 and 11, In addition, in some other fields, explicit discussion of ethical issues was taken seriously. A major example is the problem of economic development, out of which capability theories emerged (see the discussions of capability theory in chapter 12 and of Sen's work in chapter 13). For example, capability theorists and Sen have tackled explicitly methods of dealing with the issue of paternalism, focusing on the potential role of discussion and deliberation. Much work has also been done on how to conceptualize justice and how to balance the issue of justice against dimensions of welfare with which economists are more comfortable.

This is the context in which we need to think about the claim made in this book that, despite the preference of theorists for welfarist theories, when they have turned to practice, economists have frequently made non-welfarist arguments, This use of non-welfarist arguments strengthens the claim made by economists including Kenneth Boulding (1969), Amartya Sen (2004) and Anthony Atkinson (2009), that economics should become a "moral science." 13 What we mean by this is that economics should embrace discussions of ethics as one of the pillars on which normative economics should rest, abandoning the strict separation of economic science from ethics advocated by Robbins.

An important implication of such a change is that it may require a change in the way economists conceive their subject. At least until recently, economics was dominated by theory, conceived as a process involving the specification of assumptions in such a way as to make it possible to use mathematics to derive precise conclusions of general applicability. Welfarist criteria such as Pareto-efficiency, or other welfarist criterion such as utilitarianism or a modified Rawlsian criterion (maximizing the minimum utility achieved by any member of society) fitted conveniently into this approach, for they provided a precise welfare criterion that can produce very general welfare conclusions. Such criteria can be used widely, even in macroeconomic models based on representative (identical) agents, a context in which ethical

\footnotetext{
${ }^{12}$ Atkinson (2001, p. 194) cited the work of Ian Little, Jan de V. Graaff, and Tibor Scitovsky in the 1950s and the, slightly later, work of William Baumol. Hicks's manifesto, discussed in chapter 7, also dates from this period. ${ }^{13}$ The idea of economics as a moral science has, of course, a much longer history. The reason we pick out Boulding and Atkinson, is that in other settings, the implications were more complicated. In nineteenth-century Cambridge, for example, the notion of "moral sciences" had institutional as well as intellectual implications.
} 
dilemmas relating to income distribution are absent. Welfare implications can be derived using essentially the same methods as those used to derive comparative statics results from the models. In contrast, if a broader range of ethical criteria were to be used (for example, applying certain notions of justice or fairness), it would often be necessary to think about problems in different ways, for they do not always provide a criterion that can be applied mechanically to a model. As an example, take Rawls's maximin criterion. Rawls applied this to the provision of primary goods, not to overall consumption which implies that it becomes necessary to distinguish between primary and non-primary goods.

As a consequence, if economists are to take note of the conclusions reached in modern welfare economics, they may have to be open to arguments that can be expressed only verbally, or which rest on economists' ethical judgments (such as of what constitute primary goods). Atkinson (2009) provides several examples. For example, reducing social exclusion, a concept that, however meaningful, is hard to incorporate in an economic model, may be a powerful reason for targeting employment as a policy objective. If our concern is with welfare, it may make sense to focus on indicators such as the Human Development Index rather than the simpler concept of national income, or on some other index based on recent welfare and equity theories (e.g. Fleurbaey 2009, Fleurbaey and Blanchet 2013).

If economists are to be more open to conclusions reached by specialists in welfare economics and social choice theory, it is likely that they will need to be prepared to approach the subject in a different way. Welfarism, with its reliance on utilities, holds out the prospect of a completely general welfare that can be analysed using the tools traditionally used in economic theory. Broadening the set of welfare criteria to include factors such as justice, that cannot be quantified in such way that they can be measured against utility, may require going beyond economists' traditional methods. It may be necessary to engage in deliberations over factors that are not quantifiable and have to be articulated verbally. In other words, being open to a broader range of non-welfarist arguments may involve a move away from economic theory as that is commonly understood.

This is potentially a radical change, but it would reflect a change that has already taken place in relation to empirical methods (see Backhouse and Cherrier 2017). When the 2019 Nobel Prize in Economic Sciences was given to Abhijit Banerjee, Esther Duflo and Michael Kremer for their use of experimental methods to alleviate poverty, they explained that their results were different from those traditionally sought by economists. ${ }^{14}$ Their work did not produce completely general results but results tailored to specific situations. This was important because the effectiveness of policies typically depended on details of the situation that would not be apparent to a traditional economic theorist. Similarly, as large data sets have become available, economists have developed new econometric techniques in which a major concern, if not the predominant one, is identification. As a result, formal economic theory, of the type that fitted so well with the Pareto criterion and other welfarist criteria, has become less central to the field. Considering the numerous social and political practical consequences of any theoretical assertions, perhaps a similar change is required in relation to welfare economics. In the same way that some economists have become more open to psychology, and

14 The three lectures can be found at https://www.nobelprize.org/prizes/economic-sciences/2019/summary/. 
those parts of economics bordering on psychology, perhaps they should be more open to ethical philosophy and those parts of economics that engage with it, even if this means moving beyond traditional welfare economics. Only if economists move beyond welfarism and consider all relevant ethical values, will it be possible to deal with the full range of practical issues with which normative economics ought to be concerned.

\section{Bibliography for Part 2}

Arrow, K. J. (1951) An Extension of the Basic Theorems of Classical Welfare Economics, in Proceedings of the Second Berkeley Symposium on Mathematical Statistics and Probability, J. Neyman (ed.), Berkeley and Los Angeles: University of California Press: 507-532.

Atkinson, A. (2001) The strange disappearance of welfare economics. Kyklos, 54(2-3), 193-206.

Atkinson, A. (2009) Economics as a Moral Science. Economica, 76(1), 791-804.

Backhouse, R.E. \& Cherrier, B. (2017) The Age of the Applied Economist. History of Political Economy, 49(Supplement), 1-33.

Backhouse, R. and Biddle, J. (2000) The Concept of Applied Economics: A History of Ambiguity and Multiple Meanings. History of Political Economy, 32(5), 1-24

Blaug, M. (2007) The Fundamental Theorems of Modern Welfare Economics, Historically Contemplated. History of Political Economy, 39(2), 185-207.

Boulding, K. (1969) Economics as a Moral Science. The American Economic Review 59(1), 1-12.

Chipman, J. S., and Moore, J. C. 1978. The new welfare economics, 1939-1974. International Economic Review 19: $547-84$.

Debreu, G. (1951) The Coefficient of Resource Utilization. Econometrica. 19(3), 273-292.

Fleurbaey, M. 2000, Choix social : une difficulté et de multiples possibilités. Revue Economique 51(5), p. 12151232.

Fleurbaey, M. 2007, Social Choice and just institutions: new perspectives. Economics and Philosophy 23, 15-43.

Fleurbaey, M. (2009) Beyond GDP: The Quest for a Measure of Social Welfare. Journal of Economic Literature 47(4), 1029-1075.

Fleurbaey, M., and Blanchet, D. (2013) Measuring welfare and assessing sustainability. Oxford University Press.

Hicks, J. R. 1939. The foundations of welfare economics. Economic Journal 49(196), 696-712.

Igersheim, H. 2019. The Death of Welfare Economics: History of a Controversy. History of Political Economy 51(5).

Mongin, M. and P. Fleurbaey 2005 The news of the death of welfare economics is greatly exaggerated. Social Choice and Welfare, 25(2), 381-418.

Putnam, H. 2002. The Collapse of the Fact/Value Dichotomy and Other Essays, Cambridge, Mass.: Harvard University Press.

Robbins, L. An essay on the nature and significance of Economic Science, 3ème ed. Macmillan, London, 1932.

Sen, A. K. (2004) L'économie est une science morale. Paris : La Découverte, Poche. 